\title{
PENILAIAN MAHASISWA S1, S2, DAN S3 TERHADAP SUMBER DAYA PERPUSTAKAAN DI FAKULTAS PSIKOLOGI UNIVERSITAS GADJAH MADA
}

\author{
Pergola Irianti*, Agni Prasetyo**, dan Siti Hidayati***
}

\section{ABSTRACT}

This research was aimed to find out the evaluation from the students of undergraduate, graduate, and doctor program toward library resources in the Faculty of Psychology, Universitas Gadjah Mada. The result of this research was expected to give benefit to develop the library resources for giving the excellent services to the user.

This research used quantitative method, questionnaire as the data collection method, and descriptive statistic method for analizing data. The subject of this research was 159 students from undergraduate, graduate, and doctor program as the user of the library.

The results showed standard value for each program: undergraduate (2,545963), graduate comprised with Master of Science $(2,644517)$ and Master of Profession (2,541234), and doctor (2,982143). If the value higher than $(>)$ standard value included high categories and less than $(<)$ or equal with $(\Rightarrow)$ standard value included low categories.

The comprehensive result of this research showed that (1) high caitegories evaluation came from the aspects of collection relevancy, circulation, facilities (security, temperature, light, and lay out), and human resources; (2) low categories evaluation came from the aspects of collection (composition of subject and language), services (time, number of collection, duration of borrowing books, and interlibrary borrowing books), facilities (space, table, and chair), information technology (computer/internet, internet accessibility, and multimedia); and (3) variation of high-low evaluation came from the aspects of collection (recently and completeness), services (searching, multimedia, and fine), and information technology (library based on information technology and browsing).

Keywords: evaluation, library resources

***,*** Pustakawan UGM ditugaskan di Perpustakaan Fakultas Psikologi UGM

\section{A. PENDAHULUAN}

Perpustakaan perguruan tinggi merupakan salah satu sarana penunjang pendidikan, penelitian dan pengabdian kepada masyarakat. Kewajibannya melaksanakan tugas pemilihan, penghimpunan, pengolahan, perawatan, dan melayankan sumber informasi kepada lembaga induk dan sivitas akademika di lingkungannya. Perpustakaan perguruan tinggi diharapkan dapat memenuhi kebutuhan informasi pengajar maupun mahasiswa, menyediakan bahan pustaka rujukan pada semua jenjang akademis, menyediakan ruangan untuk pemakai, menyediakan jasa peminjaman serta menyediakan jasa informasi aktif bagi pengguna (Septiyantono, dkk., 2003).

Keberhasilan dan ketidakberhasilan perpustakaan dalam menyediakan layanan kepada pengguna, salah satunya dapat diketahui dari penilaian yang merupakan hasil persepsi pengguna terhadap perpustakaan. Dengan kata lain, persepsi pengguna terhadap perpustakaan bermanfaat sebagai indikator evaluasi apakah sebuah perpustakaan sudah memberikan layanan yang baik atau sebaliknya layanan yang tidak baik.

Sebagian besar pengguna perpustakaan di Fakultas Psikologi Universitas Gadjah Mada adalah mahasiswa baik dari jenjang S1, S2 program magister profesi dan program magister sain, serta mahasiswa S3. Perbedaan kebutuhan informasi atau kebutuhan literatur untuk mendukung studi mereka juga berbeda antara jenjang studi yang satu dengan yang lain. Perpustakaan harus jeli dan mampu menyediakan kebutuhan kepustakaan yang berbeda pada masingmasing jenjang studi. Permasalahan yang timbul apakah sumber daya perpustakaan di Fakultas Psikologi UGM sudah sesuai harapan mahasiswa sebagai pengguna dan memenuhi kebutuhan informasi mereka. Pertanyaan penelitian yang diajukan dalam penelitian ini adalah: bagaimana penilaian mahasiswa terhadap sumber daya perpustakaan di Fakultas Psikologi UGM. 
Penelitian ini bertujuan untuk mengetahui penilaian mahasiswa terhadap sumber daya perpustakaan di Fakultas Psikologi Universitas Gadjah Mada. Hasil penelitian diharapkan bermanfaat sebagai bahan evaluasi perpustakaan, terkait dengan sumber daya perpustakaan.

\section{B. TINJAUAN PUSTAKA}

\section{Penilaian}

Pengertian penilaian yang sebenarnya merupakan hasil dari persepsi individu terhadap objek yang ada di sekitarnya. Persepsi diartikan sebagai penglihatan, pemahaman atau tanggapan (Kamus Besar Bahasa Indonesia, 2007). Namun di dalam Ilmu Psikologi, persepsi merupakan suatu proses yang diawali dengan penginderaan. Penginderaan adalah suatu proses diterimanya stimulus oleh individu melalui alat penerima yaitu indera. Pengertian persepsi menurut beberapa ahli dikemukakan sebagai berikut. Reber dan Reber (2010) memahami persepsi sebagai kesadaran tentang proses organik, maksudnya adalah sebuah kejadian yang disadari, sebagai pengalaman aktual dari rantai proses-proses organik yang dipicu oleh sejumlah stimulus eksternal dan internal. Ahli lain seperti Harvey dan Smith, serta Wrightsman dan Deaux (dalam Martini dan Farida, 2010) mendefinisikan persepsi sebagai proses membuat penilaian (judgment) atau membangun kesan (impressum) mengenai berbagai macam hal yang terdapat dalam lapangan penginderaan seseorang.

Ada dua faktor yang mempengaruhi persepsi, yaitu faktor internal dan faktor eksternal. Walgito (2002) menjelaskan bahwa faktor internal yang terdapat dalam diri individu, berasal dari sumber yang berhubungan dengan sisi kejasmanian dan yang lain berhubungan dengan sisi psikologis. Sisi psikologis ini berupa pengalaman, cara berpikir, kerangka acuan, dan motivasi yang akan berpengaruh dalam persepsi. Sedangkan faktor eksternal terdiri dari stimulus itu sendiri dan lingkungan tempat persepsi berlangsung. Lebih lanjut dijelaskan bahwa objek persepsi yang terletak di luar orang yang mempersepsikan, dapat berwujud benda-benda, situasi, dan manusia. Objek persepsi yang berbentuk bendabenda disebut persepsi benda (thing perception) atau non-social perception. Objek persepsi berwujud manusia disebut persepsi sosial atau social perception. Persepsi sosial merupakan proses seseorang untuk mengetahui, menginterpretasikan dan mengevaluasi orang lain yang dipersepsi.

Beberapa penelitian terkait dengan persepsi pengguna terhadap perpustakaan sudah banyak dilakukan. Sepengetahuan penulis ada beberapa penelitian yang pernah dilakukan sebelumnya. Penelitian Desmita dan Suryantini (2005), mengenai karakteristik individual dan persepsi peneliti BPTP Sumatera Barat terhadap sumber daya perpustakaan dan hubungannya dengan pemanfaatan koleksi. Hasil penelitian tersebut menunjukkan besarnya kebutuhan peneliti terhadap koleksi tercetak berupa jurnal dan buku. Menurut para peneliti ini, perpustakaan akan dipersepsi bermanfaat bagi pengguna ketika dapat memenuhi kebutuhan mereka akan informasi yang dapat diperoleh dalam waktu cepat. Secara lebih spesifik penelitian ini menunjukkan bahwa tingkat pemanfaatan perpustakaan linier dengan jumlah naskah ilmiah yang dimiliki oleh perpustakaan baik berupa laporan penelitian maupun jurnal.

Seiring dengan perkembangan teknologi informasi, perpustakaan juga dituntut tidak hanya menyediakan koleksi pustaka cetak melainkan juga dalam bentuk digital. Mafar (2006) dalam penelitiannya di Perpustakaan UIN Sunan Kalijaga menunjukkan bahwa internet saat ini sudah menjadi kebutuhan pokok pengguna perpustakaan.

Penelitian Irkhamiyati dan Lasa (2007) mengenai persepsi mahasiswa terhadap kualitas pelayanan sirkulasi di perpustakaan Stikes Aisyiyah Yogyakarta, menyimpulkan bahwa persepsi positif mahasiswa terhadap perpustakaan dipengaruhi oleh kualitas layanan.

\section{Sumber Daya Perpustakaan}

Sumber daya adalah segala sesuatu baik yang berwujud maupun yang tidak berwujud yang digunakan untuk mencapai hasil, misal peralatan, sediaan, waktu, dan tenaga. Secara singkat dapat dijelaskan bahwa sumber daya perpustakaan adalah segala sesuatu yang mendukung pencapaian tujuan perpustakaan (Kamus Besar Bahasa Indonesia, 2007),

Sumber daya perpustakaan yang memadai, berpotensi mendukung tugas-tugas perpustakaan perguruan tinggi dalam hal pengembangan koleksi, mengolah dan merawat bahan pustaka, memberi layanan, serta melaksanakan 
administrasi perpustakaan. Di dalam buku Pedoman Perpustakaan Perguruan Tinggi edisi ketiga dikemukakan bahwa sumber daya perpustakaan meliputi aspek-aspek: koleksi, fasilitas fisik, fasilitas layanan, sumber daya manusia, serta fasilitas teknologi informasi (Ditjen Dikti, 2005).

Koleksi perpustakaan dapat berupa buku teks, majalah, karya tulis ilmiah, atau bahan multi media lain yang berpotensi memperkaya perpustakaan (Saleh dan Komalasari, 2000). Koleksi perpustakaan perguruan tinggi meliputi buku (monograph), majalah ilmiah (journal), karya-karya ilmiah (skripsi, tesis, disertasi, dan laporan penelitian dosen). Koleksi ini dapat berwujud cetak (hardcopy), maupun berwujud soft copy atau digital file (Ditjen Dikti, 2005). Pembinaan dan pengembangan koleksi sesuai kebutuhan pemustaka maupun instansi induk dapat mengoptimalisasi pemanfaatan koleksi. Beberapa unsur yang harus diperhatikan dalam pembinaan koleksi antara lain: relevansi, kemutakhiran, kelengkapan baik dari segi cakupan subjek, maupun jenis dan ragamnya, serta bahasa pengantar.

Fasilitas fisik utama untuk terlaksananya semua kegiatan perpustakaan adalah gedung. Gedung sekaligus ruang-ruang yang ada di dalamnya harus mampu menampung semua kegiatan, termasuk peralatan serta perabotan sebagai penunjang (Saleh dan Komalasari, 2009). Termasuk dalam fasilitas fisik perpustakaan antara lain lokasi perpustakaan, luas lantai, tata ruang, pencahayzan, suhu udara, dan perabotan. (Ditjen Dikti, 2005). Fasilitas layanan perpustakaan harus disesuaikan dengan kebutuhan penustaka, seperti: penyediaan informasi, waktu layanan yang tepat, kebebasan akses, berorientasi kepada pemustaka, dan memberi kesan yang baik (Sutarno, 2005). Pengguna dapat memperoleh informasi yang dibutuhkan secara optimal dari berbagai media, dengan menggunakan berbagai alat bantu penelusuran yang tersedia (Ditjen Dikti, 2005).

Sumber daya manusia merupakan salah satu aspek sumber daya perpustakaan untuk mencapai keberhasilan layanan perpustakaan. Staf perpustakaan harus memadai dari segi jumlah maupun mutu agar program yang dikembangkan perpustakaan untuk memenuhi kebutuhan pengguna dapat dilakukan.

Fasilitas teknologi informasi, berupa penerapan teknologi informasi dan komunikasi di perpustakaan yang menciptakan berbagai konsep dan menggambarkan pemanfaatan teknologi tersebut. Perpustakaan terotomasi dan sistem perpustakaan digital (digital library system) disebut juga dengan perpustakaan elektronik yang memiliki e-service, $e$ resource, dan lain-lain merupakan bentuk penerapan teknologi informasi di perpustakaan. Pada kenyataannya perpustakaan berbasis digital secara penuh belum mutlak dilaksanakan karena perpustakaan masih mengelola koleksi tercetak di samping koleksi digital, perpustakaan seperti ini disebut perpustakaan hibrida (Ditjen Dikti, 2005). Fasilitas pendukung teknologi informasi di perpustakaan dapat berupa telepon, komputer tersambung internet, WiFi, mesin faksmili. Fasilitas tersebut akan mempermudah layanan multimedia bagi pemustaka.

\section{METODE PENELITIAN}

Subjek penelitian adalah mahasiswa S1, S2, dan S3 yang menggunakan layanan perpustakaan. Metode pengambilan sampel dengan teknik convenient. Jumlah sampel ditentukan secara proporsional pada masing-masing jenjang studi, yaitu $10 \%$ dari jumlah populasi (Arikunto, 2006). Jumlah subjek dalam penelitian sebesar 159 mahasiswa.

Metode pengumpulan data menggunakan kuesioner. Kuesioner berisi butir-butir pertanyaan yang mencerminkan indikator dari masing-masing aspek sumber daya perpustakaan. Berikut ini indikator masing-masing aspek yang dituangkan dalam butirbutir pada kuesioner untuk mengetahui penilaian mahasiswa terhadap sumber daya perpustakaan.

1. Aspek koleksi, meliputi: relevansi, kemutakhiran, kelengkapan jenis koleksi, komposisi koleksi menurut subjek, komposisi koleksi menurut bahasa pengantar (bahasa Indonesia dan bahasa asing).

2. Aspek layanan, meliputi: jumlah jam layanan, jumlah koleksi dapat dipinjam, lama waktu pinjam, sanksi denda, layanan penelusuran, layanan sirkulasi, layanan multimedia, dan layanan pinjam antar perpustakaan.

3. Aspek fasilitas fisik, meliputi: lokasi perpustakaan, keamanan, kenyamanan (suhu ruang, cahaya, suara), luas ruangan, tata letak ruang, dan jumlah meja kursi.

4. Aspek sumber daya manusia, meliputi: skill petugas, pengetahuan/wawasan petugas, keterampilan, kemampuan analisis informasi, sikap petugas (proaktif, kecepatan, ketepatan, keramahan, dan kedisiplinan).

5. Aspek fasilitas teknologi informasi, meliputi: basis teknologi informasi, fasilitas komputer dan 
internet, akses internet, penelusuran online, dan fasilitas multimedia.

Dalam setiap butir pertanyaan disediakan empat alternatif jawaban bergradasi atau berperingkat satu sampai dengan empat. Keempat alternatif jawaban tersebut adalah: (a) kondisi tidak baik atau tidak ada menunjukkan gradasi paling rendah, diberi nilai satu; (b) kondisi kurang baik atau kurang diberi nilai dua; (c) kondisi baik diberi nilai tiga; kondisi sangat baik menunjukkan gradasi paling tinggi, diberi nilai empat.

Analisis data dengan metode deskriptif kuantitatif. Setelah data terkumpul, dilakukan penghitungan rata-rata nilai butir selanjutnya disebut nilai butir. Dalam analisis data terlebih dahulu dilakukan penghitungan nilai standar untuk menentukan tinggi rendahnya kategori penilaian setiap butir. Apabila nilai butir sama dengan atau di bawah nilai standar ( ) dikategorikan rendah. Apabila nilai butir berada di atas standar $(>)$ dikategorikan tinggi. Proses analisis data selanjutnya menggunakan komputer dengan program Microsoft Office-Excel 2010.

\section{HASIL PENELITIAN DAN PEMBAHASAN}

Setelah dilakukan analisis data, diperoleh nilai rata-rata untuk menentukan standar penilaian pada masing-masing jenjang studi sebagai berikut:

Tabel 1

Nilai standar penilaian pada masing-masing jenjang studi

\begin{tabular}{|l|c|}
\hline \multicolumn{1}{|c|}{ Jenjang Studi } & Nilai Standar \\
\hline Mahasiswa S1 & 2,545963 \\
\hline Mahasiswa S2 Profesi & 2,541234 \\
\hline Mahasiswa S2 Sain & 2,644517 \\
\hline Mahasiswa S3 & 2,982143 \\
\hline
\end{tabular}

Nilai berkategori rendah, apabila hasil penilaian sama dengan atau kurang dari nilai standar, sebaliknya apabila hasil penilaian di atas nilai standar termasuk dalam nilai berkategori tinggi (Arikunto, 2006).

\section{Hasil Penelitian}

\section{a. Koleksi}

Aspek koleksi dicerminkan dalam lima indikator yang dituangkan dalam butir-butir kuesioner. Kelima indikator tersebut adalah: relevansi koleksi, kemutakhiran, kelengkapan koleksi, komposisi koleksi menurut subjek, komposisi koleksi menurut bahasa pengantar.
Tabel 2

Penilaian mahasiswa terhadap aspek koleksi

\begin{tabular}{|l|c|c|c|c|}
\hline \multirow{2}{*}{ Indikator } & \multicolumn{4}{|c|}{ Kategori Penilaian } \\
\cline { 2 - 5 } & S1 & S2 Prof & S2 Sain & S3 \\
\hline Relevansi & T & T & T & T \\
\hline Kemutakhiran & R & R & T & R \\
\hline Kelengkapan & R & R & T & R \\
\hline Komposisi subjek & R & R & R & R \\
\hline Komposisi bahasa & R & R & R & R \\
\hline
\end{tabular}

Pada tabel di atas menunjukkan bahwa indikator relevansi koleksi mendapat penilaian berkategori tinggi dari mahasiswa S1, S2 Profesi, S2 Sain, dan S3. Indikator komposisi subjek dan komposisi bahasa mendapat penilaian berkategori rendah dari mahasiswa semua jenjang studi. Indikator kemutakhiran dan kelengkapan koleksi penilaiannya lebih bervariasi. Penilaian mahasiswa S2 Sain terhadap indikator kemutakhiran dan kelengkapan koleksi berkategori tinggi, sementara mahasiswa dari tiga jenjang studi yang lain memberi penilaian berkategori rendah.

\section{b. Layanan}

Aspek layanan dicerminkan dari delapan indikator yang dituangkan dalam butir-butir kuesioner. Kedelapan indikator tersebut adalah: jam layanan, jumlah koleksi dapat dipinjam, lama peminjaman, sangsi keterlambatan pengembalian koleksi, layanan penelusuran, layanan multimedia, layanan sirkulasi, dan layanan pinjam antar perpustakaan.

Tabel 3

Penilaian mahasiswa terhadap aspek layanan

\begin{tabular}{|c|c|c|c|c|}
\hline \multirow{2}{*}{ Indikator } & \multicolumn{4}{|c|}{ Kategori Penilaian } \\
\hline & S1 & S2 Prof & S2 Sain & S3 \\
\hline Jam layanan & $\mathrm{R}$ & $\mathbf{R}$ & $\mathbf{R}$ & $\mathrm{R}$ \\
\hline $\begin{array}{l}\text { Jumlah koleksi } \\
\text { dipinjam }\end{array}$ & $\mathbf{R}$ & $\mathbf{R}$ & $\mathbf{R}$ & $\mathrm{R}$ \\
\hline Lama peminjaman & $\mathrm{R}$ & $\mathrm{R}$ & $\mathrm{R}$ & $\mathbf{R}$ \\
\hline Sangsi & $\mathbf{R}$ & $\mathrm{R}$ & $\mathrm{T}$ & $T$ \\
\hline $\begin{array}{l}\text { Layanan } \\
\text { penelusuran }\end{array}$ & $\mathrm{T}$ & $\mathbf{R}$ & $\mathbf{R}$ & $\mathrm{T}$ \\
\hline Layanan multimedia & $\mathrm{R}$ & $\mathrm{T}$ & $\mathrm{R}$ & $T$ \\
\hline Layanan sirkulasi & $\mathrm{T}$ & $T$ & $\mathrm{~T}$ & $T$ \\
\hline $\begin{array}{l}\text { Layanan pinjam } \\
\text { antar perpustakaan }\end{array}$ & $\mathbf{R}$ & $\mathbf{R}$ & $\mathrm{R}$ & $\mathbf{R}$ \\
\hline
\end{tabular}


Pada tabel di atas menunjukkan bahwa ada empat indikator yang memperoleh penilaian rendah dari mahasiswa semua jenjang studi, yaitu jam layanan, jumlah koleksi dipinjam, lama peminjaman, dan layanan pinjam antar perpustakaan. Sebaliknya pada indikator layanan sirkulasi memperoleh penilaian berkategori tinggi. Penilaian pada beberapa indikator yang lain bersifat variatif. Indikator sangsi mendapat penilaian tinggi dari mahasiswa S2 Sain dan S3, sebaliknya mahasiswa S1 dan S2 Profesi memberikan penilaian berkategori rendah. Sementara indikator layanan penelusuran mendapat penilaian berkategori tinggi dari mahasiswa $\mathbf{S 1}$ dan $\mathbf{S} 3$, dan sebaliknya mahasiswa S2 Profesi maupun Sain memberi penilaian berkategori rendah. Penilaian berkategori tinggi juga diberikan oleh mahasiswa S2 Profesi maupun S3 terhadap indikator layanan multimedia, sementara mahasiswa S1 dan S2 Sain memberi penilaian berkategori rendah.

\section{c. Fasilitas fisik}

Ada delapan indikator yang mendukung aspek fasilitas perpustakaan, antara lain: lokasi perpustakàan, keamanan, suhu ruangan, penerangan, suara, luas ruangan, tata letak atau lay-out perpustakaan, dan jumlah meja kursi. Masing-masing indikator tersebut menjadi butir pertanyaan pada kuesioner. Tabel berikut menggambarkan penilaian mahasiswa terhadap kedelapan indikator tersebut.

\section{Tabel 4}

Penilaian mahasiswa terhadap aspek fasilitas

\begin{tabular}{|l|c|c|c|c|}
\hline \multirow{2}{*}{\multicolumn{1}{c|}{ Indikator }} & \multicolumn{4}{|c|}{ Kategori Penilaian } \\
\cline { 2 - 5 } & S1 & $\begin{array}{c}\text { S2 } \\
\text { Prof }\end{array}$ & $\begin{array}{c}\text { S2 } \\
\text { Sain }\end{array}$ & S3 \\
\hline Lokasi & R & T & R & T \\
\hline Keamanan & T & T & T & T \\
\hline Suhu ruang & T & T & T & T \\
\hline Cahaya/penerangan & T & T & T & T \\
\hline Suara & T & T & T & R \\
\hline Luas & R & R & R & R \\
\hline Tata letak & T & T & T & T \\
\hline Meja-kursi & R & R & R & R \\
\hline
\end{tabular}

Tabel di atas memperlihatkan bahwa mahasiswa pada semua jenjang studi memberikan penilaian tinggi pada indikator keamanan, suhu ruang, penerangan, dan tata letak ruang perpustakaan. Penilaian berkategori rendah ada pada dua indikator yaitu luas ruang dan jumlah meja kursi yang masih terbatas. Dua indikator yang lain yaitu lokasi dan suara, penilaiannya bervariasi.
Lokasi perpustakaan mendapat penilaian beraktegori tinggi dari mahasiswa S2 Profesi dan S3, sebaliknya penilaian berkategori rendah berasal dari mahasiswa S1 dan S2 Sain. Indikator suara mendapat penilaian berkategori tinggi pada mahasiswa S1, S2 Profesi dan S2 Sain, sebaliknya penilaian berkategori tinggi berasal dari mahasiswa S3.

\section{d. Sumber daya manusia}

Aspek sumber daya manusia perpustakaan pada penelitian ini terdiri dari: skill petugas, pengetahuan petugas, keterampilan, kemampuan analisis informasi, sikap proaktif, kecepatan layanan, ketepatan layanan, keramahan, dan kedisiplinan. Kesembilan indikator tersebut dituangkan dalam kuesioner sebagai butirbutirpertanyaan. Perolehan penilaian mahasiswa terhadap aspek sumber daya manusia dapat dilihat pada tabel 5.

Tabel 5

Penilaian mahasiswa terhadap aspek sumber daya manusia

\begin{tabular}{|l|c|c|c|c|}
\hline \multirow{2}{*}{\multicolumn{1}{|c|}{ Indikator }} & \multicolumn{4}{c|}{ Kategori Penilaian } \\
\cline { 2 - 5 } & $\mathrm{S} 1$ & $\begin{array}{c}\mathrm{S} 2 \\
\text { Prof }\end{array}$ & $\begin{array}{c}\text { S2 } \\
\text { Sain }\end{array}$ & $\mathrm{S3}$ \\
\hline Skill petugas & $\mathrm{T}$ & $\mathrm{T}$ & $\mathrm{T}$ & $\mathrm{T}$ \\
\hline Pengetahuan petugas & $\mathrm{T}$ & $\mathrm{T}$ & $\mathrm{T}$ & $\mathrm{T}$ \\
\hline Keterampilan petugas & $\mathrm{T}$ & $\mathrm{T}$ & $\mathrm{T}$ & $\mathrm{T}$ \\
\hline Kemampuan analisis & $\mathrm{T}$ & $\mathrm{T}$ & $\mathrm{T}$ & $\mathrm{T}$ \\
\hline Sikap proaktif & $\mathrm{T}$ & $\mathrm{T}$ & $\mathrm{T}$ & $\mathrm{T}$ \\
\hline Kecepatan layanan & $\mathrm{T}$ & $\mathrm{T}$ & $\mathrm{T}$ & $\mathrm{T}$ \\
\hline Ketepatan layanan & $\mathrm{T}$ & $\mathrm{T}$ & $\mathrm{T}$ & $\mathrm{T}$ \\
\hline Keramahan petugas & $\mathrm{T}$ & $\mathrm{T}$ & $\mathrm{T}$ & $\mathrm{T}$ \\
\hline Kedisiplinan petugas & $\mathrm{T}$ & $\mathrm{T}$ & $\mathrm{T}$ & $\mathrm{T}$ \\
\hline
\end{tabular}

Terlihat pada tabel di atas bahwa mahasiswa semua jenjang studi memberi penilaian berkategori tinggi terhadap semua indikator dalam aspek sumber daya manusia di Perpustakaan Fakultas Psikologi UGM.

\section{e. Fasilitas teknologi informasi}

Aspek fasilitas teknologi informasi meliputi lima indikator yaitu: basis teknologi informasi, fasilitas komputer dan internet, aksesibilitas internet, penelusuran informasi online, dan fasilitas multimedia. Kelima indikator tersebut dituangkan dalam butir-butir pertanyaan pada kuesioner. $\mathrm{L}$ e b i h jelasnya penilaian mahasiswa terhadap aspek fasiitas teknologi informasi di perpustakaan Fakutas Psikologi UGM dapat dilihat pada tabel berikut. 
Tabel 6

Penilaian mahasiswa terhadap aspek fasilitas teknologi informasi

\begin{tabular}{|l|c|c|c|c|}
\hline \multirow{2}{*}{\multicolumn{1}{|c|}{ Indikator }} & \multicolumn{4}{|c|}{ Kategori Penilaian } \\
\cline { 2 - 5 } & S1 & $\begin{array}{c}\text { S2 } \\
\text { Prof }\end{array}$ & $\begin{array}{c}\text { S2 } \\
\text { Sain }\end{array}$ & S3 \\
\hline Basis teknologi informasi & T & R & T & T \\
\hline $\begin{array}{l}\text { Fasilitas komputer \& } \\
\text { internet }\end{array}$ & $\mathbf{R}$ & $\mathbf{R}$ & $\mathbf{R}$ & $\mathbf{R}$ \\
\hline Akses internet & $\mathbf{R}$ & $\mathbf{R}$ & $\mathbf{R}$ & $\mathbf{R}$ \\
\hline Penelusuran online & T & R & T & T \\
\hline Fasilitas multi media & $\mathbf{R}$ & $\mathbf{R}$ & $\mathrm{R}$ & $\mathbf{R}$ \\
\hline
\end{tabular}

Tabel di atas memperlihatkan bahwa mahasiswa pada semua jenjang studi memberikan penilaian berkategori rendah terhadap indikator fasilitas komputer/internet, aksesibiitas internet, dan fasilitas multimedia. Pada dua indikator yang lain penilaiannya lebih bervariasi. Indikator basis teknologi informasi dan penelusuran online, mahasiswa program magister profesi memberi penilaian berkategori rendah sedangkan tiga jenjang program studi yang lain memberi penilaian berkategori tinggi. Indikator basis teknologi *informasi memperoleh penilaian berkategori tinggi dari mahasiswa S1, S2 Sain dan S3, dan sebaliknya mendapat penilaian berkategori rendah dari mahasiswa program S2 Profesi.

\section{Pembahasan}

Penilaian mahasiswa terhadap sumber daya perpustakaan secara keseluruhan disajikan dalam tabel berikut.

Tabel 7

Kategori penilaian mahasiswa terhadap sumber daya perpustakaan secara keseluruhan

\begin{tabular}{|c|c|c|c|}
\hline Aspek & $\begin{array}{c}\text { Kategori } \\
\text { Tinggi }\end{array}$ & $\begin{array}{l}\text { Kategori } \\
\text { Rendah }\end{array}$ & Bervariasi \\
\hline Koleksi & $\begin{array}{l}\text { Relevansi } \\
\text { koleksi }\end{array}$ & $\begin{array}{l}\text { Komposisi } \\
\text { subjek, } \\
\text { komposisi } \\
\text { bahasa }\end{array}$ & $\begin{array}{l}\text { Kemutakhiran, } \\
\text { kelengkapan }\end{array}$ \\
\hline Layanan & $\begin{array}{l}\text { Layanan } \\
\text { sikulasi }\end{array}$ & $\begin{array}{l}\text { Jam layanan, } \\
\text { jumlah koleksi } \\
\text { dipinjam, lama } \\
\text { peminjaman, } \\
\text { pinjam antar } \\
\text { perpustakaan }\end{array}$ & $\begin{array}{l}\text { Layanan } \\
\text { penelusuran, } \\
\text { layanan } \\
\text { multimedia, } \\
\text { sanksi }\end{array}$ \\
\hline $\begin{array}{l}\text { Fasilitas } \\
\text { fisik }\end{array}$ & $\begin{array}{l}\text { Keamanan, } \\
\text { suhu, } \\
\text { cahaya, } \\
\text { tata letak }\end{array}$ & $\begin{array}{l}\text { Luas ruang dan } \\
\text { meja-kursi }\end{array}$ & Lokasi \\
\hline $\begin{array}{l}\text { Sumber } \\
\text { daya } \\
\text { manusia }\end{array}$ & $\begin{array}{l}\text { Semua } \\
\text { indikator }\end{array}$ & Tidak ada & \\
\hline $\begin{array}{l}\text { Teknologi } \\
\text { Informasi }\end{array}$ & Tidak ada & $\begin{array}{l}\text { Komputer/internet, } \\
\text { aksesibilitas } \\
\text { internet, fasilitas } \\
\text { multimedia }\end{array}$ & $\begin{array}{l}\text { Basis TI, } \\
\text { penelusuran } \\
\text { online }\end{array}$ \\
\hline
\end{tabular}

Tabel di atas menunjukkan bahwa semua indikator aspek sumber daya manusia perpustakaan mendapat penilaian berkategori tinggi dari mahasiswa semua jenjang studi. Kondisi ini perlu dipertahankan dan akan lebih baik lagi apabila ditingkatkan. Beberapa pernyataan mahasiswa yang mendukung kondisi tersebut antara lain sebagai berikut: "jaga profesionalisme yang sudah ada", "SDM sudah oke".

Penilaian berkategori tinggi oleh mahasiswa semua jenjang studi juga diberikan pada beberapa indikator yaitu: relevansi koleksi, layanan sirkulasi, keamanan, suhu, cahaya, dan tata letak ruang. Diharapkan kondisi tersebut masih dapat ditingkatkan, setidaknya dapat dipertahankan.

Penilaian berkategori rendah yang diberikan oleh mahasiswa semua jenjang studi diberikan pada beberapa indikator, yaitu: komposisi subjek, komposisi, bahasa, jam layanan, jumlah koleksi dipinjam, lama peminjaman, pinjam antar perpustakaan, luas ruang, meja kursi, komputer/ internet, aksesibilitas internet, fasilitas multimedia. Beberapa pernyataan disampaikan oleh mahasiswa terkait dengan kondisi tersebut antara lain: "koleksi psikologi olah raga dan kepelatihan masih kurang", "koleksi terbaru sangat kurang" dan "koleksi buku baru kurang, masih banyakyang jadul", "jam layanan sangat kurang", "buka hingga malam hari". Pernyataan yang terkait dengan fasilitas teknologi informasi antara lain: "Kecepatan internet harap dinaikkan", "akses digital buruk, kurang up date, downloadjurnal lama".

Penilaian bervariasi diberikan pada beberapa indikator antara lain: kemutakhiran, kelengkapan, layanan penelusuran, layanan multimedia, sangsi, lokasi, basis TI, dan penelusuran online. Ada beberapa indikator yang memperoleh penilaian berkategori tinggi, dan sebaliknya ada pula yang memperoleh penilaian berkategori rendah. Oleh karena itu perlu pembenahan dan peningkatan pada semua indikator tersebut.

\section{E. KESIMPULAN DAN SARAN}

\section{Kesimpulan}

Kesimpulan yang dapat diambil dari penelitian ini adalah belum semua aspek sumber daya perpustakaan memperoleh penilaian berkategori tinggi, kecuali aspek sumber daya manusia. Aspek sumber daya manusia memperoleh penilaian berkategori tinggi dari mahasiswa semua jenjang studi yang ada di Fakultas Psikologi UGM. Aspek-aspek yang lain seperti aspek 
koleksi, aspek layanan, aspek fasilitas, dan aspek teknologi informasi penilaian berkategori tinggi masih terbatas pada beberapa indikator saja.

\section{Saran}

Berdasarkan temuan penelitian ini, disarankan kepada perpustakaan termasuk instansi induk dalam hal ini pihak fakultas untuk memberi dukungan dalam peningkatan sumber daya perpustakaan. Empat dari lima aspek sumber daya perpustakaan yang perlu mendapat perhatian untuk ditingkatkan adalah koleksi, layanan, fasilitas, dan teknologi informasi. Beberapa masukan dan saran untuk perpustakaan sebagai berikut:

a. Penambahan koleksi berbahasa Indonesia dan menyeimbangkan jumlah koleksi berdasarkan subjek kajian.

b. Penambahan jam layanan, penambahan jumlah koleksi dapat dipinjam dan waktu peminjaman. Sosialisasi pinjam antar perpustakaan ditingkatkan.

c. Fasilitas komputer internet ditambah jumlahnya, demikian pula dengan aksesibilitasnya supaya ditingkatkan sehingga lebih lancar koneksitasnya, dan penambahan peralatan multimedia yang memadai.

Meskipun aspek sumber daya manusia perpustakaan memperoleh penilaian dengan kategori tinggi pada semua indikator, namun upaya untuk meningkatkan keterampilan dan pengembangan kepribadian perlu dilakukan secara terus-menerus.

\section{DAFTAR PUSTAKA}

Arikunto, Suharsimi. 2006. Prosedur penelitian suatu pendekatan praktik. Rineka Cipta, Jakarta.

Desmita \& Suryantini, H. 2005. Karakteristik individual dan persepsi peneliti terhadap sumber daya perpustakaan dan hubungannya dengan pemanfaatn koleksi. Jurnal Perpustakaan Pertanian. Vol.14, No.1 (1-9).

Ditjen Dikti, 2005. Perpustakaan Perguruan Tinggi. Buku Pedoman, edisi ketiga. Depdiknas Ditjen Dikti, Jakarta
Gunatirin, 1996. Kemampuan peniliaian subjek penelitian Indonesia: pengulangan dan modifikasi penelitian Bernieri, Glis \& Davis (1992) tentang dukungan terhadap teori penilaian sosial. Tesis. Program Pascasarjana UGM, Yogyakarta.

Irkhamiyati \& Lasa HS, 2008. Persepsi mahasiswa terhadap kualitas pelayanan sirkulasi di Perpustakaan Stikes Aisyiyah Yogyakarta. Berkala Ilmu Perpustakaan dan Informasi, Vol. III, No.7(51-62). Perpustakaan UGM, Yogyakarta.

Pusat Bahasa Depdiknas. 2007. Kamus Besar Bahasa Indonesia, Edisi ketiga. Balai Pustaka, Jakarta.

Mafar, F. 2006. Persepsi pengguna terhadap layanan internet di UPT Perpustakaan UIN SUKA Yogyakarta tahun 2005. Skripsi. Jurusan Ilmu Perpustakaan Fakultas Adab UIN SUKA, Yogyakarta.

Martini, N.A. \& Farida, I. 2010. Materi pokok psikologi perpustakaan. Universitas Terbuka, Jakarta.

Reber, A.S. \& Reber, E.S. 2010. Kamus Psikologi (diterjemahkan dari judul asli: The Penguin Dictionary of Psychology, oleh Yudi Santoso). Pustaka Pelajar, Yogyakarta.

Saleh, A.R. dan Komalasari, R. 2009. Manajemen Perpustakaan. Universitas Terbuka: Jakarta.

Septiyantono, T. \& Sidik, U. 2003. Dasar-dasar ilmu perpustakaan dan informasi. Jurusan Ilmu Perpustakaan dan Informasi, Fakultas Adab IAIN Sunan Kalijaga, Yogyakarta.

Sutarno N.S. 2005. Tanggung Jawab Perpustakaan dalam mengembangkan masyarakat informasi. Panta Rei, Jakarta.

Walgito, B. 2002. Psikologi sosial. Suatu pengantar. Andi Offset, Yogyakarta. 


\title{
PERJALANAN PENERAPAN SISTEM INFORMASI OPEN SOURCE KOHA DI PERPUSTAKAAN UNIVERSITAS MUHAMMADIYAH SURAKARTA DARI TAHUN 2006 s.d. 2010
}

\author{
Oleh: Maria Husnun*
}

\begin{abstract}
The title of the research is "The chronology of the application of open source information system Koha in the library of Muhammadiyah University of Surakarta from 2006 to 2010." The background of this research is that the development of the information technology demands the library to use the technology. UMS' library was the first private-university library using Koha system as the automatic system in Indonesia.Koha's complete features and its development raised confusion among UMS' library staff. The use of English language and the small number of the community of Koha users in Indonesia sometimes lead to misinterpretation.

The method used in this research was the qualitative method, and its approach was the case study. The reason of using these was that the case happened was unique and the forms of the questions were how and why.

The result of the research was that there were 3 periods of the chronology of Koha application in UMS library, namely: pre-Koha, whilst using Koha, and developing of Koha system.The application of Koha system in UMS library had been in accordance with the cycle of the development of the information system. This cycle includes planning, analyzing, system designing, implementing, operating, evaluating, and developing. The influential factors were: (1) the rectorat's supports, (2) human resource and leadership, (3) trend in the library, (4) integration, (5) the need of the system, (6) the data analyze, (7) communication, (8) good cooperation, (9) socialization, (10) open source, (11) financial condition, (12) the quality of the system, (13) the readiness of the facilities. Besides, the research found that there were some new factors as the theoretical contributions namely: good communication and cooperation, socialization, and the readiness of the facilities. It also found that there was one lost factor, namely: user interface.
\end{abstract}

Key words: Information system, KOHA system.

* Mahasiswa MIPUGM

\section{A. Pendahuluan}

Perkembangan teknologi informasi dan komunikasi yang begitu cepat menuntut perpustakaan sebagai lembaga informasi menggunakan teknologi informasi sebagai alat untuk menjalankan kegiatan sehari-hari. Pemanfaatan teknologi informasi sudah menjadi kebutuhan mutlak bagi perpustakaan untuk mencapai efisiensi dan efektifitas pengelolaan perpustakaan. Melalui teknologi komputer dan informasi yang semakin maju memungkinkan kemudahan-kemudahan dalam pengelolaan perpustakaan. Sistem otomasi dan digitalisasi perpustakaan akan memberi peluang akses yang lebih besar kepada pengguna dan meringankan kerja staf perpustakaan.

Perpustakaan Universitas Muhammadiyah Surakarta (UMS) sejak tahun 1994 sudah menerapkan otomasi dengan sistem pustaka, yang kala itu hanya terbatas pada bagian pengolahan dan penelusuran buku. Tahap selanjutnya pada tahun 2004 berganti sistem informasi Mypus yang berhasil mengotomasikan bagian pengolahan dan penelusuran buku serta bagian sirkulasi dan administrasi anggota. Namun semakin banyak data dan masih sederhana mypus, menuntut perpustakaan UMS untuk kembali mengganti sistem informasi perpustakaannya. Setelah melalui tahap pemilihan, analisis, penilaian dan pertimbangan akhirnya pada Februari 2008 perpustakaan UMS secara resmi memilih dan memanfaatkan sistem informasi perpustakaan open source Koha dalam pengelolaan perpustakaannya.

Koha memiliki fitur yang lengkap dibandingkan dengan sistem open source lainnya dan dapat digunakan untuk semua ukuran perpustakaan. Fiturfitur tersebut dapat digunakan sebagai sistem dalam sirkulasi, katalogisasi, akuisisi, serial, cadangan, manajemen pengelolaan, maupun pengelolaan cabang perpustakaan, dengan daya tampung data yang besar. Koha menggunakan desain database dual yang memanfaatkan kekuatan dari dua jenis database standar industri besar (berbasis teks dan RDBMS). Fitur desain memastikan bahwa Koha dapat dipakai 